\title{
First evidence of Fogo Island skink (Chioninia fogoensis) introduction to the island of Madeira
}

\author{
DAVID J. CLEMENS* \& STEVEN J. R. ALLAIN
}

Cambridgeshire \& Peterborough Amphibian and Reptile Group

*Corresponding author e-mail: lutonreptilerescue@hotmail.co.uk

$T^{\mathrm{h}}$ he Madeiran wall lizard (Teira dugesii) is the only native reptile species found on Madeira, although other species such as the Tenerife lizard (Gallotia galloti) and moorish gecko (Tarentola mauritanica) have been introduced to the island and become established (Arnold \& Burton, 2002; Jesus et al., 2013). Madeira lacks any native snakes however the flower pot snake (Indotyphlops braminus) has been accidentally introduced to the island, likely by the movement of horticulture products from the Canary Islands (Jesus et al., 2013). There are a number of other reptile (and amphibian) species recorded from Madeira, however these likely represent single individuals that may have escaped captivity and therefore do not represent self-sustaining breeding populations (Malkmus, 2004). Madeira's depauperate herpetofauna assemblage is probably due to its relative isolation in the Atlantic Ocean, being $700 \mathrm{~km}$ off the west coast of Africa and about $900 \mathrm{~km}$ from the Iberian Peninsula (Jesus et al., 2013).

In mid-December 2019, an elderly couple returned to Britain from a holiday in Madeira to find a skink in their suitcase. Upon discovering the emaciated lizard they contacted the RSPCA (Royal Society for the Prevention of Cruelty to Animals) who rehomed the skink with an exotic pet dealer. From here the lizard found a permanent home with DJC (in mid-January 2020) and it has been in his care since (Fig. 1). Due to the emaciated nature of the skink, a robust identification was not possible until fairly recently. The individual was easily identified as a skink due to the lack of femoral pores. After consulting with other herpetologists the skink was successfully identified as the Fogo Island skink (Chioninia fogoensis) following information in Miralles et al. (2010). Whilst we do not know where in Madeira the holidaymakers were staying we do know that this island was their only holiday destination. There is no evidence to suggest that the aircraft in which the couple travelled landed anywhere prior to arrival back in London. Consequently, the simplest explanation is that the skink entered their luggage whilst holidaying in Madeira.

The Fogo Island skink is endemic to the island of Santo Antão, Cape Verde although before a recent taxonomic split, subspecies were thought to be more widespread among neighbouring islands (Miralles et al., 2010). These subspecies have since been elevated to species level, reducing the potential source of $C$. fogoensis to a single island. Tropical house geckos (Hemidactylus mabouia) also originating from

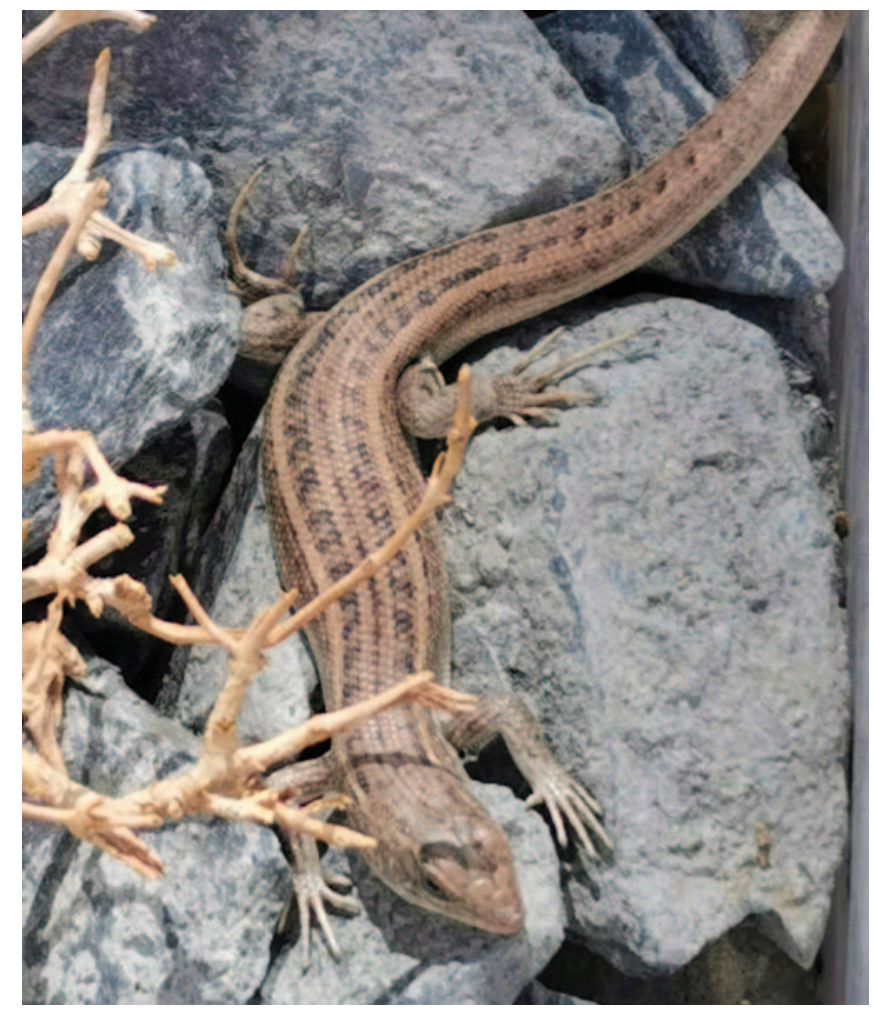

Figure 1. Fogo Island skink (C. fogoensis) in a temporary enclosure in Britain some weeks following air travel from Maderia in a suitcase

Cape Verde have been introduced to Madeira in recent times (Jesus et al., 2002). Madeira and the Cape Verde archipelago are over $1900 \mathrm{~km}$ apart separated by the Atlantic Ocean which rules out natural dispersal of either species. As both territories are former colonies of Portugal, it is likely that there are established trade routes by which the introduction of such reptiles could occur.

The native fauna of Madeira has also been a source of colonists; the endemic T. dugesii has been introduced to the Azores, Canary Islands and mainland Portugal (Silva-Rocha et al., 2016). Such movements risk the introduction of their diseases or parasites, which could potentially threaten native species (Burridge, 2001). Research suggests that $T$. dugesii is a potential host for tick-borne pathogens (De Sousa et al., 2012) that may be novel to lizards, people and livestock in the extended range.

Up until now, C. fogoensis has likely gone undetected on 
Madeira as it is similar in appearance to native lizards. No records of $C$. fogoensis occurring outside its natural range (including Madeira) were found through HerpMapper or iNaturalist. However, this isn't the first time a skink from the genus Chioninia has entered Britain as a stowaway. In 2012, a Chioninia sp. stowed away in the baggage of a holiday maker returning from Cape Verde (Morris, 2012). This specimen not only survived the flight back to the UK but also being washed with clothes in the washing machine on a 30 min 'delicates' cycle. The species is clearly very robust.

Based on the evidence available $C$. fogoensis is likely to have colonised Madeira recently and one or more breeding populations may be present. Further surveys are needed to confirm this.

\section{ACKNOWLEDGEMENTS}

We'd like to thank Julian Clare for homing the skink at Wrigglies until a more permanent home could be found. We'd also like to thank Stuart Graham, Francis Cosquieri, Robert Pilley and Darrel Raw for their help and input in narrowing down the identity of skink.

\section{REFERENCES}

Arnold, E. N. \& Burton, J. A. (2002). Field Guide to the Reptiles and Amphibians of Britain and Europe. London, HarperCollins. p. 288.

Burridge, M. J. (2001). Ticks (Acari: Ixodidae) spread by the international trade in reptiles and their potential roles in dissemination of diseases. Bulletin of Entomological Research 91: 3-23.
De Sousa, R., Lopes de Carvalho, I., Santos, A. S., Bernardes, C., Milhano, N., Jesus, J., Menezes, D. \& Nuncio, M. S. (2012). Role of the lizard Teira dugesii as a potential host for Ixodes ricinus tick-borne pathogens. Applied and Environmental Microbiology 78: 3767-3769.

Jesus, J., Freitas, A. I., Brehm, A. \& Harris, J. (2002). An introduced population of Hemidactylus mabouia (Moreau de Jonnés, 1818) on Madeira Island. Herpetozoa 15: 179180.

Jesus, J., Goncalves, R., Spinola, C. \& Brehm, A. (2013). First record of Ramphotyphlops braminus (Daudin, 1803) on Madeira Island (Portugal). Herpetozoa 26: 106-109.

Malkmus, R. (2004). Amphibians and Reptiles of Portugal, Madeira and the Azores-Archipelago: Distribution and Natural History Notes. Ruggell, A.R.G. Gantner Verlag. 488 pp.

Miralles, A., Vasconcelos, R., Perera, A., Harris, D. J. \& Carranza, S. (2010). An integrative taxonomic revision of the Cape Verdean skinks (Squamata, Scincidae). Zoologica Scripta 40: 16-44.

Morris, S. (2012). 'Lizard survives 3,000 miles in suitcase and 30 minutes in washing machine' The Guardian, 7 February, Available at: https://www.theguardian.com/ world/2012/feb/07/lizard-survives-suitcase-washingmachine (Accessed 18th April 2020).

Silva-Rocha, I., Sá-Sousa, P., Fariña, B. \& Carretero, M. A. (2016). Molecular analysis confirms Madeira as source for insular and continental introduced populations of Teira dugesii (Sauria: Lacertidae). Salamandra 52: 269-272.

Accepted: 21 April 2020 